\title{
Marketing of Live Poultry in Northwest of Dhaka City - A Value Chain Analysis
}

\author{
Islam S. ${ }^{1, *}$, Begum J. ${ }^{1}$, Hossain M. I. ${ }^{2}$, Khatun M. ${ }^{1}$ \\ ${ }^{1}$ Socioeconomic Research Division; Bangladesh Livestock Research Institute, Savar, Dhaka \\ ${ }^{2}$ Department of Agri-business and Marketing; Bangladesh Agricultural University, Mymensingh \\ *Corresponding author: s.islam_blri@yahoo.com
}

\begin{abstract}
The poultry sub-sector contributing a lot in expediting economic growth and abating malnutrition for the people of Bangladesh. This study attempts to identify the actors involved in value chain and their functions, and to estimate the value addition of different actors in live poultry marketing; Spatial and seasonal price fluctuations of poultry also investigated by using secondary data. Primary data were collected by using pretested questionnaire from the 250 respondents distributing 150 farmers, 70 traders and 50 consumers. Tabular, graphical, simple statistics and ratio to moving average were used for reaching the objectives. The prime market actors performed marketing functions were poultry farmers, faria, beparie, wholesalers and retailers. The longer marketing channel was found for native chicken followed by broiler and sonali. The production costs per quintal of live poultry were BDT 7,300, BDT 17,063 and BDT 9,488, respectively for native chicken, sonali and broiler. The net return was found BDT 5,182 , BDT 3,714 and BDT 1,123 per quintal, respectively for native, sonali and broiler. Total marketing cost of native chicken was 1.24 times higher than sonali and 1.21 times higher than broiler. In terms of net marketing margins native chickens market actors received 5.44 times higher return than broiler and 1.93 times higher return than sonali. Among the different market actors for native chicken, faria incurred highest marketing cost followed by retailer and bepari. For the sonali and broiler bird marketing, retailer incurred highest cost followed by bepari and wholesaler. Among intermediaries of poultry marketing retailers received highest net margin although they incurred second highest marketing cost. The percentages of total value addition cost and total net profit by different intermediaries for native chicken, major cost was borne by retailers and major net profit was earned by retailers. For sonali bird marketing, major cost was borne by retailers and major net profit was earned by bepari. For broiler marketing, major cost was borne by retailers and major net profit is earned by retailers. The seasonal price indices of broiler at retail level price in Dhaka Sadar and Savar market during 2010 to 2014, the price index was highest in the month of June and July and lowest in the month of November and December, respectively. In retail level the coefficient of variation of broiler is highest in Dhaka Sadar followed by Savar. It revealed that at Dhaka Sadar price risk of broiler is higher compare to Savar. The national level coefficients of variation of native chicken were found highest for medium followed by small and large size of birds. Majority of the consumers showed negative opinion in case of processed poultry meat. As live poultry marketing brought serious health diseases where near about $58 \%$ of market actors suffered different diseases. For sustainable and environment friendly poultry business need to ensure bio-security, halal method and hygienic way of poultry processing.
\end{abstract}

Keywords: live poultry, market actors, marketing system, value addition

Cite This Article: Islam S., Begum J., Hossain M. I., and Khatun M., "Marketing of Live Poultry in Northwest of Dhaka City -A Value Chain Analysis." American Journal of Food and Nutrition, vol. 5, no. 1 (2017): 28-40. doi: 10.12691/ajfn-5-1-4.

\section{Introduction}

Poultry sub-sector in the agrarian country like Bangladesh brings livelihood change of the rural people. Poultry meat alone contributes 36 per cent of total meat production in Bangladesh [2]. Poultry also contributes about $22 \%$ to $27 \%$ of the national animal protein supply [9]. This sub-sector has proved as an attractive economic activity by generating employment of more than 5 million of people and mitigating nutritional deficiency. The people benefits greatly from poultry meat and eggs, which provide food containing high-quality protein, and a low level of fat with a desirable fatty acid profile. In financial year 2014-15, Bangladesh produced 3122.93 lakh poultry, where chicken 2617.70 lakh and duck 505.22 lakh [5]. Although meat production has been increasing over the year but the per capita availability $(2.92 \mathrm{~kg} / \mathrm{year})$ is far below the standard requirement $(7.67 \mathrm{~kg} /$ year $)$ [3]. The meat demand is growing due to increasing trend of population and change in food habit. Therefore, there is huge gap between demand and supply. As a result, farmers and other market actors supply live poultry birds quickly for getting higher benefit without protecting any health measures which hinder the industry for sustaining 
production. The most dangerous disease affecting human health is Avian Influenza and Newcastle disease which are transmitted mostly through live poultry bird transaction and transportation. These diseases are very much contagious and spread out very quickly over the areas. Live poultry bird marketing through changing ownership by buying and selling is a major disease transmission pathway. A developing country like Bangladesh, live bird transaction and marketing activities is a very common phenomenon due to the religious beliefs and consumer preferences. This live bird markets (LBMs) are sat in mainly beside the road and the markets are unhygienic. There are two types of LBMs in Bangladesh i.e., retail shops and traditional LBMs where minimal food safety standards or veterinary inspection are implemented. Most LBMs (Live Bird Market) are connected to one another, suggesting that the LBM network may support large-scale disease spread. It also may promote Trans boundary virus circulation. The poultry meat trade in Bangladesh also depends mainly on LBMs because of insufficient slaughterhouses, lack of marketing infrastructure, and cultural preference for consumption of freshly slaughtered poultry. Despite the contribution of poultry sector to the economy, the production system is not adequately market oriented. There are a number of obstacles to overcome before small farmers can get remunerative price as well as profit from poultry production. A number of studies have been conducted in the field of poultry sub-sector of Bangladesh. Uddin et al. [11] studied economics of native poultry rearing, Dolberg (2008) studied poultry sector country review, CLP [4] examined market assessment of native chickens, and Islam [8] conducted demand projections for poultry in Bangladesh. None of them examined the marketing system of poultry in the value chain perspective. Given this backdrop, this study is focused marketing of live poultry birds as well consumer preferences and provide alternative policy guidelines for sustaining the production.

\section{Methodology}

Savar Upazila in the northwest region of Dhaka City is the leading poultry production and trading area. It has also location advantage and good prospect of poultry marketing in future. For these reasons Savar Upazila was purposively selected as the study area. The samples include the native chicken (indigenous), sonali (Pakistani) and broiler producers and traders who were involved in poultry marketing were selected as respondent. The selected samples were consisted of 150 farmers (taking 50 of each), 70 traders (including 10 Faria for native chicken, 15 Bepari considering 5 from each, 15 wholesaler considering 5 from each, and 30 retailers considering 10 from each) and 50 consumers. The total sample size was 270.

To understand the disease transmission and health hazard caused by live poultry marketing and to find out the alternative ways to improve the marketing system. The study conducted KII in different selected locations. The participants of these KII were the DLS and BLRI personnel. It also conducted FGD at selected Upazila taking both intermediaries and consumers. The survey schedule was prepared according to the need of the objectives. In order to collect data, three different types of interview schedules were carefully prepared; one for farmers, one for traders and the rest for consumers. All the schedules were pre-tested. The final schedules were prepared after necessary corrections and modifications. Data were collected both from primary and secondary sources. Primary data were mainly collected through faceto-face interviews. Farm gate prices were known from farias/ beparis and consumers level prices from retailers. Secondary data were collected from documents of various reports, Bangladesh Bureau of Statistics [2] and Department of Agricultural Marketing (DAM). Primary data were collected during the months of October 2014 to January 2015. The descriptive and statistical methods were used for the analysis of data.

Network analysis mainly graphical technique was performed for this identification. First, market actors were identified. Second, volume of trade through each actor was measured. Third, a market chain was drawn. And finally, the pathway of disease transmission was explored for live poultry marketing.

To determine the seasonal variations, co-efficient of variation of big and small size poultry prices were calculated. The following formula was used for calculating co-efficient of variation (Gupta, 1988, p. 2-49):

$$
C V=\frac{\text { Standard Deviation }}{\text { Mean }} \times 100 \text {. }
$$

The marketing margin and net margin of value chain actors were estimated by the following formula:

$$
G M_{i}=P_{R_{i}}-P_{P_{i}}
$$

Where,

$\mathrm{GM}_{\mathrm{i}}=$ Gross margin (BDT/ Quintal live poultry) for ith intermediaries

$\mathrm{P}_{\mathrm{Ri}}=$ Price received (BDT/Quintal live poultry) by ith intermediaries

$\mathrm{P}_{\mathrm{Pi}}=$ Price paid (BDT/Quintal live poultry) by ith intermediaries

$$
N M_{i}=G M_{i}-M C_{i}
$$

Where,

$\mathrm{NM}_{\mathrm{i}}=$ Net margin (BDT/Quintal live poultry) for ith intermediaries

$\mathrm{MC}_{\mathrm{i}}=$ Marketing cost incurred (BDT/Quintal live poultry) for ith intermediaries

$$
\begin{aligned}
& \text { Value addition }(\%) \\
& =\frac{(\text { Sales price }- \text { Purchase price })}{\text { Purchase price }} \times 100 .
\end{aligned}
$$

Farmers' share was calculated by the following formula:

$$
\begin{aligned}
& \text { Farmers' share to the consumers' taka } \\
& =\frac{\text { Price received by the farmer }}{\text { Price paid by the retailers }} \times 100 \text {. }
\end{aligned}
$$

In order to calculate seasonal price indices of poultry ratio to moving average method ([1], pp-125-140) was applied. 


\section{Results and Discussion}

\subsection{Live Poultry Value Chain Actors and the Value Chain Map}

Input supplier: Live poultry value chain starts from the input suppliers such as DOC, feed, medicine, veterinary service from DLS, transport service providers, credit from Bank and NGOs, relatives and money lender (mohajons) are key inputs of poultry production. So, input suppliers play an important role in live poultry value chain.

Poultry producer: Poultry producers are very important actor in poultry production and marketing value chain. They are producer cum seller. Farmers generally sold their poultry to market actors either in the markets or at the farmyards and thus forward a linked in the poultry value chain map. Farmers usually sold their poultry at farmyard to faria, bepari, wholesalers, retailers and even to consumers.
Faria: Faria is a petty trader or small scale businessmen that purchased poultry species from the farmers in the village or in the local market and sold to bepari. Sometimes they sold directly to wholesalers.

Bepari: Bepari is a relatively big and non-licensed trader who purchased poultry at farmyard or local market from both the farmers and faria and sold to wholesalers. Their volume of business was larger than that of faria and possessed more capital. They have no fixed business premises.

Wholesaler: Wholesaler is a trader who have fixed establishment in the market place with adequate storage facilities. They have some hired labour and part-time/ fulltime salaried staff for performing various functions related to live poultry marketing.

Retailer: Retailer the last link in the poultry value chain. Purchase poultry from bepari and wholesaler and sold to ultimate consumers.

Consumer: Consumers are the final users and most important actors of live poultry value chain.

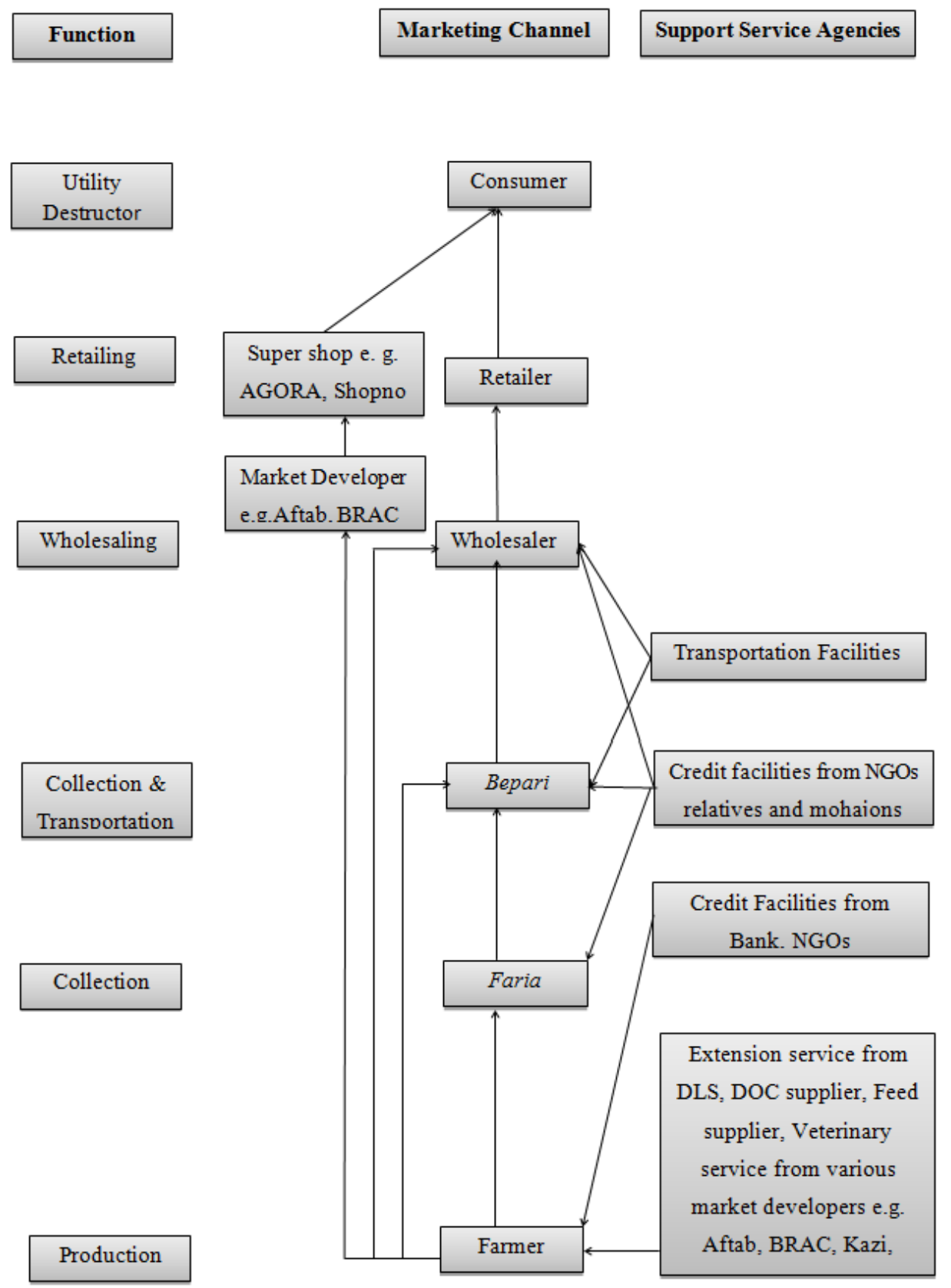

Figure 1. Value Chain Map of Live Poultry 


\subsection{Marketing and Supply Channel of Live Poultry}

Marketing is the connecting link between producers and consumers. The marketing system operates through a set of intermediaries performing useful commercial functions in a chain all the way from producers to ultimate consumers. In the areas, the entire marketing of live poultry has been broken down into various functions such as buying, selling, transportation, market information and pricing.

\subsection{Involvement of Market Intermediaries in Live Poultry Marketing}

Involvements of market actors in supply chain as well as value chain of live poultry are presented here. The prime market actors performed marketing functions are poultry farmer, farias, beparies, wholesalers, retailers and consumers in the areas.

Poultry farmer: In Savar, the farmers sold their poultry at home to faria, bepari, wholesaler, retailer and consumer at farmyard or at local market. Native chicken farmer sold 30 per cent to faria, 45 per cent to bepari, 8 per cent to wholesaler, 12 per cent to retailer and 5 per cent to ultimate consumer. In case of sonali, farmer sold 71 per cent to bepari, 22 per cent to wholesaler and 7 per cent to retailer. The broiler producing farmer sold 80 to bepari, 15 per cent wholesaler and 5 per cent to retailer (Table 1).

Faria: Farias are market actors whom are seen only for native chicken and purchased 100 per cent live poultry from native chicken farmers from their village or from the local market and sold 70 per cent to bepari and 30 per cent to wholesaler (Table 1).

Bepari: Beparies are professional traders. In case of native chicken, bepari purchased 60 per cent from farmers and 40 per cent from farias. They sold 49 per cent to wholesaler, 44 per cent to retailer and 7 per cent to consumers. In case of sonali, bepari purchased 100 per cent from farmer and sold 46 per cent to wholesaler and 54 per cent to retailer. In case of broiler, bepari purchased 100 per cent from farmers and sold 65 to wholesaler and 35 per cent to retailer (Table 1$)$.

Wholesaler: Wholesalers are the traders who transact huge volume of live poultry. In case of native chicken, they purchased 28 per cent from farias and 72 per cent from beparis and sold 98 per cent to retailers and the rest to consumers. The sonali wholesaler purchased 77 per cent from farmer and 23 per cent from beparis and sold 100 per cent to retailer. In case of broiler, wholesaler purchased 19 per cent from farmers and 81 per cent from beparies and 100 per cent sold to retailers (Table 1).

Retailer: The retailers purchased almost 80 per cent from wholesaler and the rest of from beparies and farmers and sold 100 per cent to consumers (Table 1).

Consumer: As consumers are the destructors of utility. They purchased 2 per cent native chicken from farmers and 98 per cent from retailers. In case of sonali bird, consumers purchased $3 \%, 2 \%$ and $95 \%$, from bepari, wholesaler and retailer, respectively. On the other hand, consumers purchased boiler 100 per cent from retailers (Table 1).

Table 1. Percentage of live poultry transacted by value chain actors

\begin{tabular}{|c|c|c|c|c|c|c|c|c|c|c|}
\hline \multirow{2}{*}{$\begin{array}{l}\text { Actors } \\
\text { Native }\end{array}$} & \multicolumn{5}{|c|}{ Purchase from (\%) } & \multicolumn{5}{|c|}{ Sold to $(\%)$} \\
\hline & Farmer & Faria & Bepari & Wholesaler & Retailer & Faria & Bepari & Wholesaler & Retailer & Consumer \\
\hline Farmer & 100 & - & - & - & - & 30 & 45 & 8 & 12 & 5 \\
\hline Faria & 100 & - & - & - & - & - & 70 & 30 & - & - \\
\hline Bepari & 60 & 40 & - & - & - & - & - & 49 & 44 & 7 \\
\hline Wholesaler & - & 28 & 72 & - & - & - & - & - & 98 & 2 \\
\hline Retailer & 3 & - & 12 & 85 & - & - & - & - & - & 100 \\
\hline Consumer & 2 & - & - & - & 98 & - & - & - & - & - \\
\hline \multicolumn{11}{|l|}{ Sonali } \\
\hline Farmer & 100 & - & - & - & - & - & 71 & 22 & 7 & - \\
\hline Bepari & 100 & - & - & - & - & - & - & 46 & 54 & - \\
\hline Wholesaler & 77 & - & 23 & - & - & - & - & - & 100 & - \\
\hline Retailer & - & - & 17 & 83 & - & - & - & - & - & 100 \\
\hline Consumer & - & - & 3 & 2 & 95 & - & - & - & - & - \\
\hline \multicolumn{11}{|l|}{ Broiler } \\
\hline Farmer & 100 & - & - & - & - & - & 80 & 15 & 5 & - \\
\hline Bepari & 100 & - & - & - & - & - & - & 65 & 35 & - \\
\hline Wholesaler & 19 & - & 81 & - & - & - & - & - & 100 & - \\
\hline Retailer & 7 & - & 22 & 71 & - & - & - & - & - & 100 \\
\hline Consumer & - & - & - & - & 100 & - & - & - & - & - \\
\hline
\end{tabular}

Source: Field survey 2015 and author's calculation. 


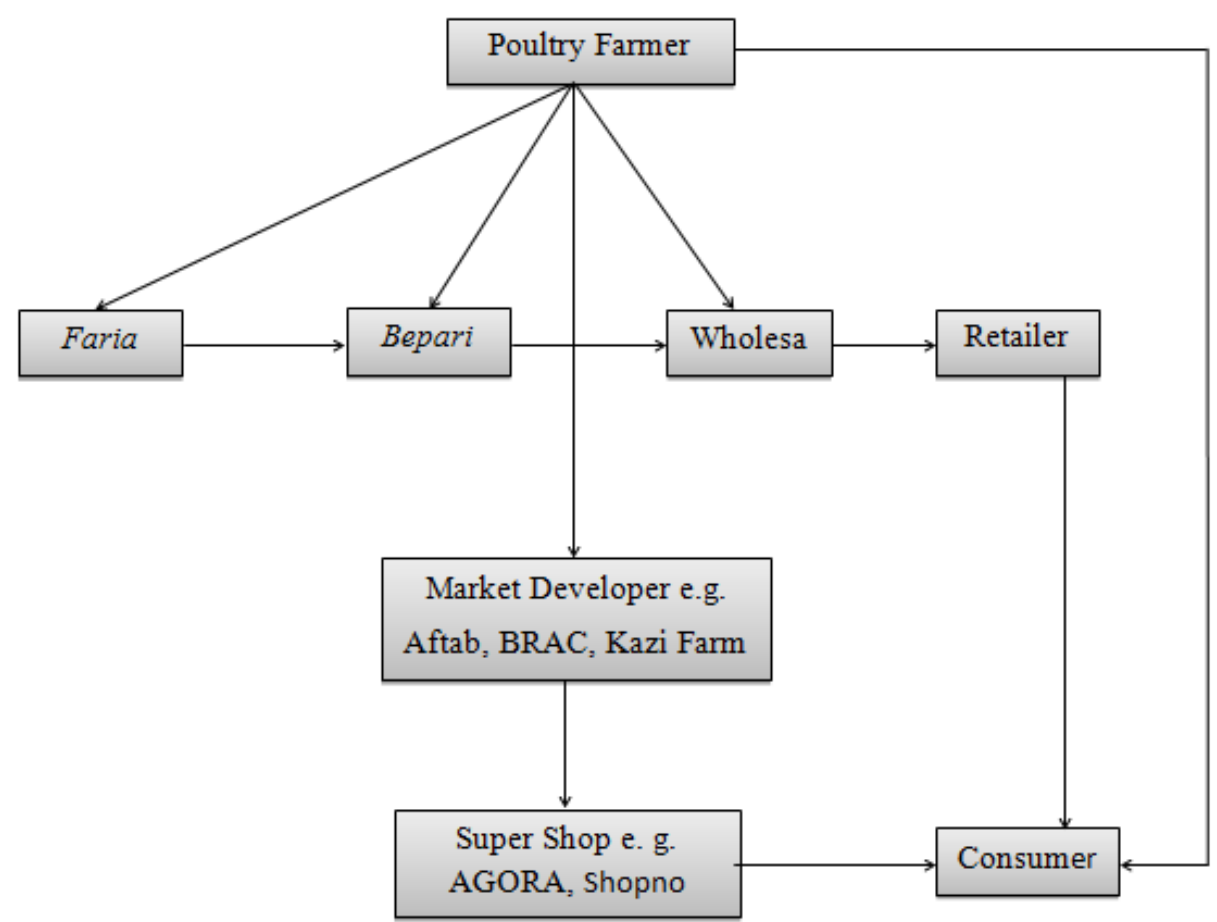

Figure 2. Live Poultry Marketing Flow Chart in Savar Upazila

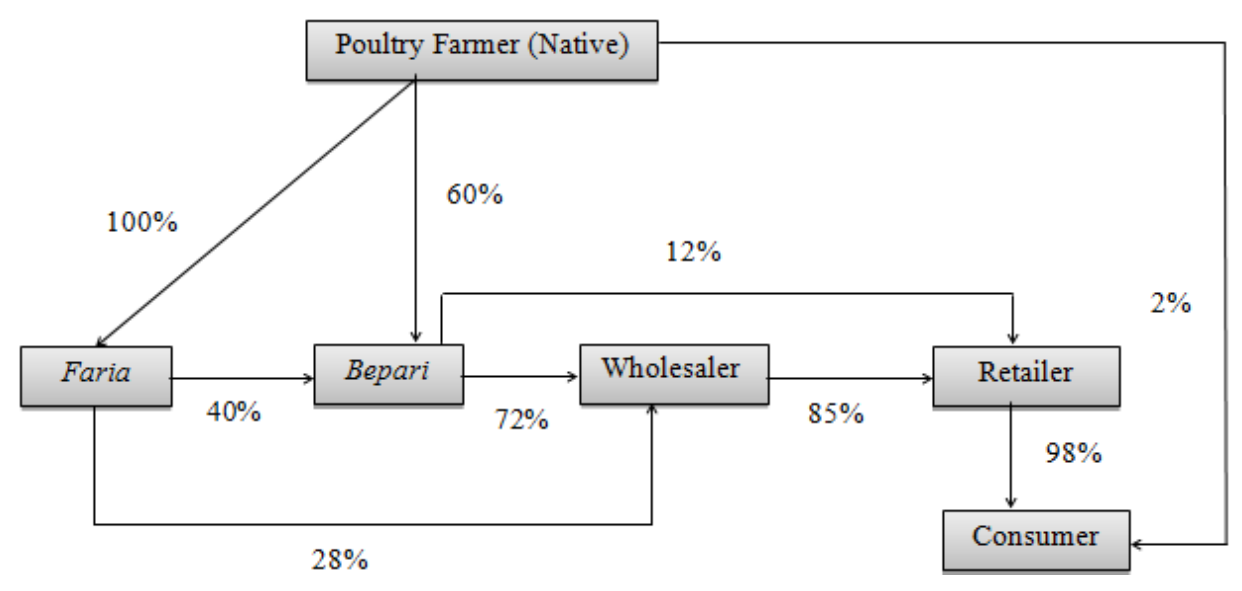

Figure 3. Marketing Flow Chart of Live Native Chicken Movement

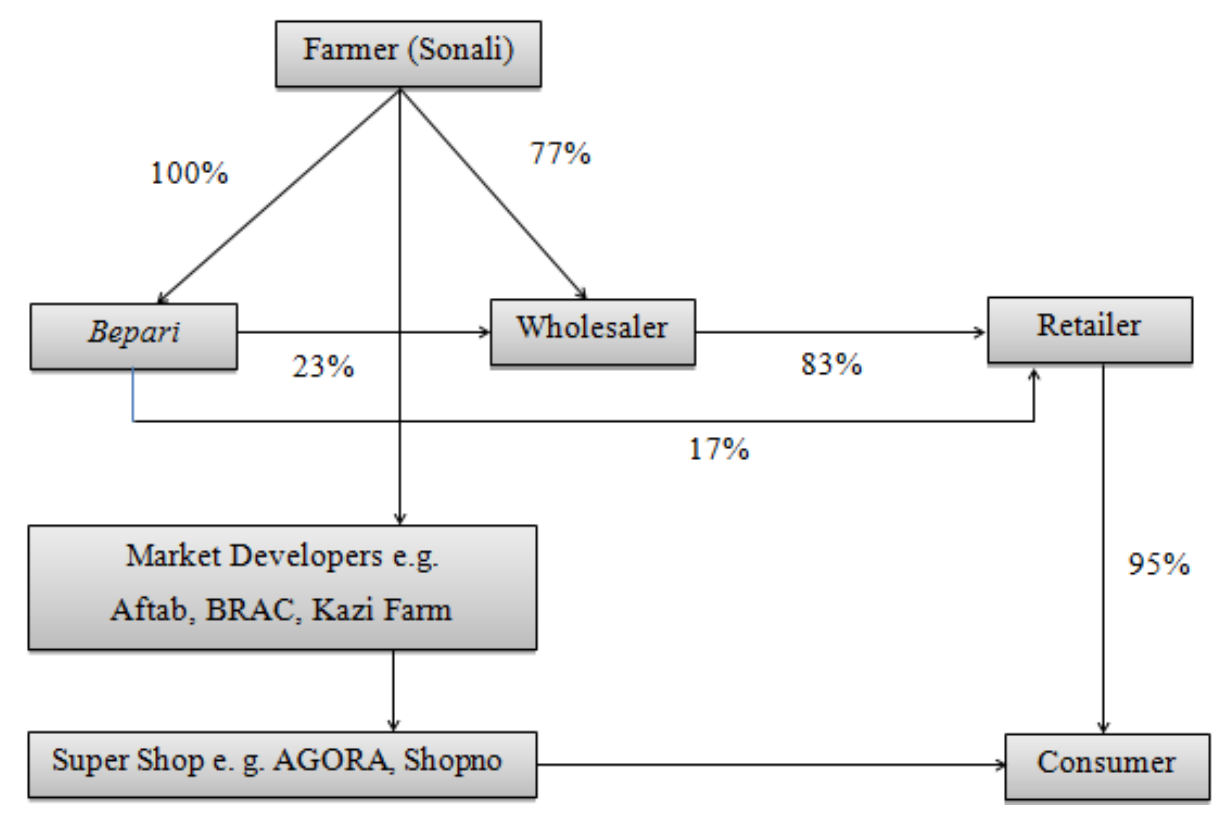

Figure 4. Marketing Flow Chart of Live Sonali Bird Movement 


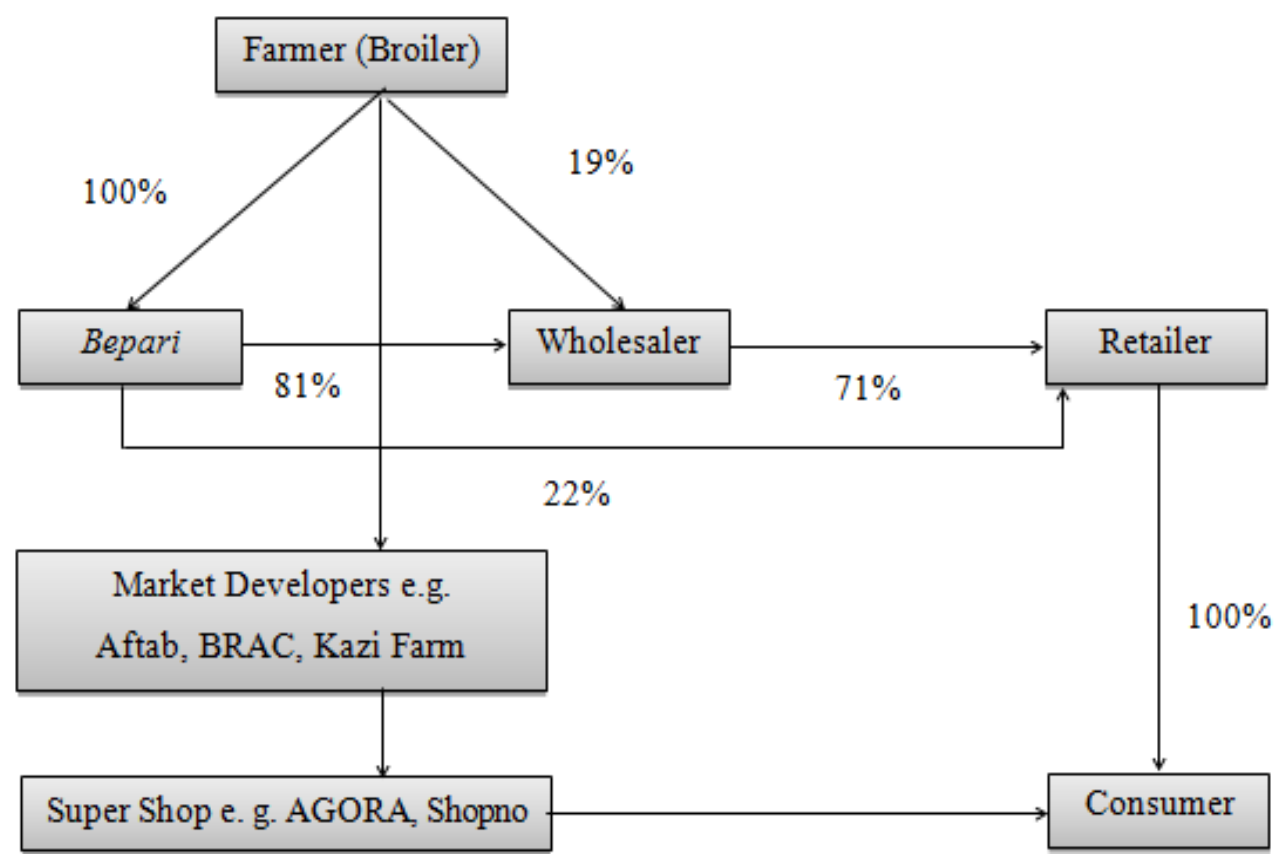

Figure 5. Marketing Flow Chart of Live Broiler Movement

\subsection{Live Poultry Value Chain Analysis}

Value chain considered three types of utility: (i) time utility (ii) place utility and (iii) form utility. In live poultry value chain is considered only time and place utility. Value is added in live poultry marketing channel by the change of its trading place and time being. Main markets of live poultry for the study were Rajfulbaria, Nobinagar Kitchen Market, Savar Bazar, Pollibidhut, Baipail Bazar, Hemayetpur Bazar, Nayar hut, Mirzanagar, Ghenda Bazar, Kathghora, Pundhua Bazar, Gherua Bazar, Mirertekh, Baipail Bazar, Polashbari and Pathalia.

In Savar, a plenty of live poultry production and trading was observed. Farmers are producing poultry species in a very large quantity. The value chain of live poultry in Savar consist of a good number of stakeholders like input suppliers such as DOC, feed, medicine (veterinary services), farmers, local collectors as farias, beparies, wholesaler and retailers. The actors lead to decrease in potential income loss of the farmers.

\subsection{Cost of Poultry Producers and Market Intermediaries}

\subsubsection{Cost of farmers}

The cost refers to total amount of funds used in poultry production and selling in this study. Total cost of poultry production is the sum of production cost and marketing cost.

Production cost: Production cost of poultry per quintal $(100 \mathrm{~kg})$ incurred by the farmers in the production process treated as production cost. In the study, only variable cost is considered for estimating the cost items. Variable inputs were as DOC, medicine \& vaccine, feed, electricity, liter cost, labour cost etc. It is revealed that for producing $100 \mathrm{~kg}$ poultry species, sonali incurred highest amount of cost that is BDT 17,063 followed by broiler BDT 9,488 and native BDT 7300. The average cost was calculated BDT 11283 per quintal (Table 2).

\subsubsection{Marketing Cost of faria}

There was little cost of faria in marketing of live poultry. As they invest less and earn less. In this study, market actors' faria was found or existed only in native chicken marketing channel. Faria incurred BDT 390 per quintal of native chicken as marketing cost. In this case, transportation cost was higher than the other cost items (Table 3).

Marketing cost of bepari: It was found that per quintal bepari incurred highest marketing cost for sonali was BDT 262 followed by broiler BDT 246 and native chicken BDT 217. Transportation cost was the highest among the cost items. Labour cost was next to transportation. The average marketing cost was BDT 242 per quintal of live poultry (Table 4).

Table 2. Production cost of poultry farmers

BDT/Qtl.

\begin{tabular}{cccccc}
\hline Sl. No. & Cost Items & Natives & Sonali & Broiler & All average \\
\hline 1. & DOC/Chicken & 3643 & 3163 & 2340 & 3049 \\
2. & Medicine \& Vaccine & 518 & 745 & 463 & 575 \\
3. & Feed & 1681 & 11930 & 6239 & 6617 \\
4. & Electricity & - & 379 & 119 & 249 \\
5. & Liter cost & - & 221 & 118 & 170 \\
6. & Labor cost & 1457 & 625 & 208 & 763 \\
\hline 7. & Total cost & 7300 & 17063 & 9488 & 11284 \\
\hline
\end{tabular}

Source: Field survey 2015 and author's calculation.

Table 3. Marketing cost of faria

BDT/Qtl

\begin{tabular}{ccc}
\hline S1. No. & Cost Items & Natives \\
\hline 1. & Transportation cost & 235 \\
2. & Marketing Tools/Tax & 50 \\
3. & Loss due to death & 105 \\
\hline 4. & Total cost & 390 \\
\hline
\end{tabular}

Source: Field survey 2015 and author's calculation. 
Table 4. Marketing cost of bapari

BDT/Qt1.

\begin{tabular}{cccccc}
\hline Sl. No. & Cost Items & Natives & Sonali & Broiler & All average \\
\hline 1. & Transportation cost & 112 & 103 & 96 & 103 \\
2. & Labor cost/Handling cost & 22 & 75 & 71 & 56 \\
3. & Loss due to death & 52 & 49 & 46 & 49 \\
4. & Feed cost & 32 & 35 & 33 & 33 \\
\hline 5. & Total cost & 218 & 262 & 246 & 242 \\
\hline
\end{tabular}

Source: Field survey 2015 and author's calculation.

Table 5. Marketing cost of wholesaler

BDT/Qtl.

\begin{tabular}{|c|c|c|c|c|c|}
\hline Sl. No. & Cost Items & Natives & Sonali & Broiler & All average \\
\hline 1. & Transportation cost & 53 & 31 & 55 & 46 \\
\hline 2. & Labor cost/Handling cost & 43 & 38 & 81 & 54 \\
\hline 3. & Marketing Tools/Tax & 20 & 14 & 22 & 19 \\
\hline 4. & Loss due to death & 61 & 38 & 49 & 49 \\
\hline 5. & House Rent & 24 & 28 & 27 & 26 \\
\hline 6. & Feed cost & 35 & 28 & 36 & 33 \\
\hline 7. & Total cost & 206 & 178 & 270 & 218 \\
\hline
\end{tabular}

Source: Field survey 2015 and author's calculation.

Table 6. Marketing cost of retailer

BDT/Qt1.

\begin{tabular}{cccccc}
\hline Sl. No. & Cost Items & Natives & Sonali & Broiler & All average \\
\hline 1. & Transportation cost & 96 & 102 & 113 & 104 \\
2. & Labor cost/Handling cost & 105 & 107 & 86 & 99 \\
3. & Marketing Tools/Tax & 30 & 56 & 65 & 50 \\
4. & Loss due to death & 30 & 60 & 68 & 53 \\
5. & House Rent & 50 & 85 & 45 & 60 \\
6. & Feed cost & 95 & 130 & 110 & 412 \\
\hline 7. & Total cost & 406 & 540 & 487 & 478 \\
\hline
\end{tabular}

Source: Field survey 2015 and author's calculation.

Table 7. Return of the farmers

\begin{tabular}{cccccc} 
& & & BDT/Qtl. \\
\hline S1. No. & Items & Natives & Sonali & Broiler & All average \\
\hline 1. & Bird sale & 24900 & 18900 & 10553 & 18118 \\
2. & Liter & - & 177 & 58 & 118 \\
3. & Gross Return & 24900 & 20777 & 10611 & 18763 \\
4. & Total Cost & 7300 & 17063 & 9488 & 11284 \\
\hline 5. & Net Return & 17600 & 3714 & 1123 & 7479 \\
\hline 6. & BCR & 3.41 & 1.22 & 1.12 & 1.66 \\
\hline
\end{tabular}

Source: Field survey 2015 and author's calculation.

Marketing cost of wholesaler: Wholesaler had various cost items such as transport cost, labor cost, marketing tools, loss due to death, house rent and feed cost etc. Study found that the cost was highest for broiler was BDT 269 followed by native chicken BDT 206 and BDT 178 respectively per quintal poultry species. The average marketing cost of wholesaler was estimated BDT 478 (Table 5).
Marketing cost of retailers: The marketing cost of retailers which was varying from poultry species to species. Study revealed that the marketing cost of sonali was the highest (BDT 540) followed by broiler (BDT 487) and native (BDT 406). The average marketing cost was estimated BDT 478 per quintal of live poultry (Table 6).

Returns of poultry farmers: During the study period per kilogram sold price for native chicken was BDT 290 
followed by sonali BDT 212 and Broiler BDT 117. The study also found that among the poultry species, the highest percentage of consumer of poultry was occupied by broiler $(67 \%)$ followed by sonali $(19 \%)$ and native chicken $(14 \%)$. The highest net return was calculated for native chicken (BDT 17,600) followed by sonali BDT 3,714 and broiler BDT 1,123 per quintal, respectively. The average net return was calculated BDT 7,479 per quintal of live poultry. The BCR were $3.41,1.22$ and 1.12 , respectively for native chicken, sonali and broiler (Table 7).

\subsubsection{Return of Market Intermediaries}

Return of faria: The marketing profit of foria for native chicken was calculated BDT 2,010 per quintal of live poultry (Table 8 ).
Return of bepari: Bepari got the highest marketing profit from sonali (BDT 1,038) followed by native chicken BDT 483 and broiler BDT 254 per quintal, respectively. The average marketing profit of bepari was calculated BDT 591 per quintal of live poultry (Table 9).

Table 8. Marketing return of foria

\begin{tabular}{ccc} 
& & BDT/Qtl. \\
\hline Sl. No. & Items & Natives \\
\hline 1. & Purchase Price (PP) & 24900 \\
2. & Sale Price (SP) & 27300 \\
3. & Marketing Margin (MM= SP-PP) & 2400 \\
4. & Marketing Cost (MC) & 390 \\
\hline 5. & Marketing Profit (MP= MM-MC) & 2010 \\
\hline
\end{tabular}

Source: Field survey 2015 and author's calculation.

Table 9. Marketing return of bapari

\begin{tabular}{|c|c|c|c|c|c|}
\hline S1. No. & Items & Natives & Sonali & Broiler & All average \\
\hline 1. & Purchase Price (PP) & 27300 & 18900 & 10500 & 18900 \\
\hline 2. & Sale Price (SP) & 28000 & 20200 & 11000 & 19733 \\
\hline 3. & Marketing Margin (MM= SP-PP) & 700 & 1300 & 500 & 833 \\
\hline 4. & Marketing Cost (MC) & 217 & 262 & 246 & 242 \\
\hline 5. & Marketing Profit $(\mathrm{MP}=\mathrm{MM}-\mathrm{MC})$ & 483 & 1038 & 254 & 591 \\
\hline
\end{tabular}

Source: Field survey 2015 and author's calculation.

Table 10. Return of Wholesaler

\begin{tabular}{|c|c|c|c|c|c|}
\hline Sl. No. & Items & Natives & Sonali & Broiler & All average \\
\hline 1. & Purchase Price (PP) & 28000 & 19600 & 10800 & 19467 \\
\hline 2. & Sales Price (SP) & 28500 & 20400 & 11300 & 20067 \\
\hline 3. & Marketing Margin (MM= SP-PP) & 500 & 800 & 500 & 600 \\
\hline 4. & Marketing Cost (MC) & 206 & 178 & 270 & 218 \\
\hline 5. & Marketing Profit (MP=MM-MC) & 294 & 622 & 230 & 382 \\
\hline
\end{tabular}

Source: Field survey 2015 and author's calculation.

Table 11. Return of retailers

\begin{tabular}{|c|c|c|c|c|c|}
\hline & & & & & BDT/Qtl \\
\hline S1. No. & Items & Natives & Sonali & Broiler & All average \\
\hline 1. & Purchase Price (PP) & 28500 & 20400 & 11300 & 20067 \\
\hline 2. & Sale Price (SP) & 31000 & 21800 & 12200 & 21667 \\
\hline 3. & Marketing Margin (MM=SP-PP) & 2500 & 1400 & 900 & 1600 \\
\hline 4. & Marketing Cost (MC) & 406 & 540 & 487 & 478 \\
\hline 5. & Marketing Profit (MP=MM-MC) & 2094 & 860 & 413 & 1122 \\
\hline
\end{tabular}

Source: Field survey 2015 and author's calculation.

Table 12. Cost and net margin of market actors

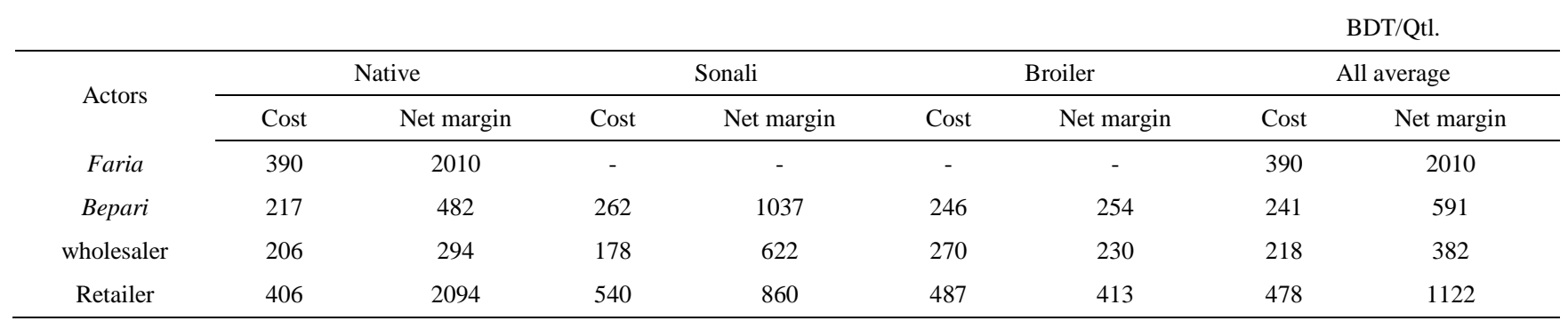

Source: Field survey 2015 and author's calculation. 
Return of wholesalers: Wholesaler earned the highest profit from sonali BDT 622 followed by native chicken BDT 294 and broiler BDT 230 per quintal, respectively. The average marketing profit of wholesaler was calculated BDT 382 per quintal of live poultry (Table 10).

Return of retailers: The returns of retailers were estimated in different poultry species. Per quintal, retailer made the highest profit from native chicken BDT 2094 followed by sonali BDT 860 and broiler BDT 413, respectively. The average marketing profit was calculated BDT 1122 per quintal (Table 11).

The study also found the significance difference of marketing costs and net margins across the bird species. The total marketing cost of native chicken was 1.24 times higher than sonali and 1.21 times higher than broiler indicating that native chicken markets need to be more attention for reducing marketing cost. In terms of net marketing margins native chickens market actors received 5.44 times higher return than broiler and 1.93 times higher return than sonali. Among the different market actors for native chicken, faria incurred highest marketing cost followed by retailer and bepari. For the sonali and broiler bird marketing, retailer incurred highest cost followed by bepari and wholesaler. Among the intermediaries of the poultry marketing retailers received highest net margin although they incurred second highest marketing cost (Table 12).

\subsection{Value Addition}

The actors of live poultry added value by changing its place that means place utility is functioning here. The value addition among the live poultry value chain actors in Savar was depicted in Table 13. It is observed from table that the all value chain actors i.e. faria, bepari, wholesaler and retailer added different types of value. In case of native chicken, faria added $9.64 \%$, bepari $2.56 \%$, wholesaler $1.79 \%$, and retailer $8.77 \%$, respectively. The facts to light about sonali, bepari added $6.88 \%$, wholesaler $4.08 \%$ and retailers $8.77 \%$, respectively. In case of broiler, bepari added $4.76 \%$, wholesaler $4.63 \%$ and retailer $7.97 \%$, respectively (Table 13).

The percentages of total value addition cost and total net profit by different intermediaries for native chicken, major cost was borne by retailers (33\% of total cost) and major net profit was earned by retailers (43\% of total net profit). For sonali bird marketing, major cost was borne by retailers (55\% of total cost) and major net profit was earned by beparis ( $41 \%$ of total net profit). For broiler marketing, major cost was borne by retailers $(49 \%$ of total cost) and major net profit is earned by retailers (46\% of total net profit) (Table 14).

\subsection{Farmers' Share to Consumer's Taka}

In 1998, the USDA reported that the farm-to-retail price spread, which represents the difference between the amount farmers receive for the goods they produce and the retail price consumers pay for food in food stores, had been increasing every year for the past 30 years (United States Department of Agriculture, 1999). Thus, food price comprises of both farm prices paid to producers and charges for marketing services such as processing and distributing.

Poultry farmers' share of different species of poultry is reasonable in the study areas. The value chain analysis of poultry species such as native chicken, sonali and broiler conducted in 2015 revealed that farmers received $87 \%$, $93 \%$ and $93 \%$, respectively of consumer's price (Table 15 ).

Table 13. Value addition by different market actors

\begin{tabular}{|c|c|c|c|c|}
\hline & & & & BDT/Qt1. \\
\hline \multicolumn{5}{|c|}{ Native } \\
\hline Value Chain & Faria & Bepari & Wholesaler & Retailer \\
\hline Sales Price & 27300 & 28000 & 28500 & 31000 \\
\hline Purchase Price & 24900 & 27300 & 28000 & 28500 \\
\hline Value addition $(\%)$ & 9.64 & 2.56 & 1.79 & 8.77 \\
\hline \multicolumn{5}{|c|}{ Sonali } \\
\hline Sales price & - & 20200 & 20400 & 21800 \\
\hline Purchase Price & - & 18900 & 19600 & 20400 \\
\hline Value Addition (\%) & - & 6.88 & 4.08 & 6.86 \\
\hline \multicolumn{5}{|c|}{ Brioler } \\
\hline Sales Price & - & 11000 & 11300 & 12200 \\
\hline Purchase Price & - & 10500 & 10800 & 11300 \\
\hline Value Addition (\%) & - & 4.76 & 4.63 & 7.97 \\
\hline
\end{tabular}

Source: Field survey 2015 and author's calculation.

Table 14. Percentage of total value addition cost and total profit of market actors

\begin{tabular}{|c|c|c|c|c|c|c|}
\hline \multirow[b]{2}{*}{ Intermediaries } & \multicolumn{2}{|c|}{ Native } & \multicolumn{2}{|c|}{ Sonali } & \multicolumn{2}{|c|}{ Broiler } \\
\hline & $\begin{array}{l}\% \text { of total value } \\
\text { addition cost }\end{array}$ & $\begin{array}{c}\% \text { of total } \\
\text { profit }\end{array}$ & $\begin{array}{c}\% \text { of total value } \\
\text { addition cost }\end{array}$ & $\begin{array}{c}\% \text { of total } \\
\text { profit }\end{array}$ & $\begin{array}{l}\% \text { of total value } \\
\text { addition cost }\end{array}$ & $\begin{array}{c}\% \text { of total } \\
\text { profit }\end{array}$ \\
\hline Faria & 31.99 & 41.18 & - & - & - & - \\
\hline Bepari & 17.8 & 9.88 & 26.73 & 41.16 & 24.54 & 28.32 \\
\hline Wholesaler & 16.9 & 6.02 & 18.16 & 24.69 & 26.91 & 25.64 \\
\hline Retailer & 33.31 & 42.91 & 55.1 & 34.14 & 48.55 & 46.04 \\
\hline
\end{tabular}

Source: Field survey 2015 and author's calculation.

Table 15. Farmers' share to consumers' taka

\begin{tabular}{cccc}
\hline Native & Sonali & Broiler & All \\
\hline $87.37 \%$ & $92.64 \%$ & $92.92 \%$ & $90.98 \%$ \\
\hline
\end{tabular}

\section{Seasonal Price Variation}

Seasonal price behaviour is regularly repeating price pattern that is completed once in every twelve months such a regular pattern might arise from seasonality in 
demand, seasonality in supply and marketing or a combination of the both ([10], pp. 157-159). Price is the indispensable component in leading production, consumption and formulation of government policies. Price stability is a key factor for economic decision making process in agriculture and rest of the economy. A set of reasons which influence much to volatile and movement of price. Agricultural or farm productions are much more prone to price variation than non-farm productions. Poultry and poultry products are the same in nature to price function. Poultry production increased, the price fallen and vice versa. Moreover, the demand for poultry and poultry products depends on some seasonal festivals i.e, Ramadan, Puja, Eid, Marriage Ceremony and various parties.

\section{Seasonal Price Variation Measurement}

In order to study seasonality in prices, seasonal indices were conducted by 12 months centred moving averages. The calculated indices were adjusted in such a way that the sum of seasonal indices for 12 months adds up to exactly 1200 . The monthly wholesale and retail price of broiler and native chicken during 2010 to 2014 in Dhaka Sadar, Savar Market and National Level were collected from Department of Agricultural Marketing Office (DAM) and DAM website.

Seasonal price variations of broiler \& native chicken in retail level and national level during 2010 to 2014 are shown below:

Seasonal price variation of broiler at retail level in Dhaka Sadar

The seasonal price indices of broiler at retail level price in Dhaka Sadar during 2010 to 2014 are presented in Appendix Table 1. It is cleared from the table that the price index was highest in the month of June (111) and lowest in the month of November (85).

Seasonal price variation of broiler at retail level in Savar

The seasonal price indices of broiler at retail level price in Savar during 2010 to 2014 are shown in Appendix Table 2. It is evident from the table that the price index was highest in the month of July (111.26) and lowest in the month of December (84).

Seasonal price variation of large size native chicken (Above 900gm) at National level

The seasonal price indices of large size native chicken at national level during 2010-2014 are shown in Appendix Table 3 . It is found from the table that the price index was highest in the month of June (105.64) and lowest in the month of January (92.97).

Seasonal price variation of medium size native chicken (Above 700-850gm) at National level

The seasonal price indices of medium size native chicken at national level during 2010-2014 are shown in Appendix Table 4. The table showed that the price index was highest in the month of August (108.85) and lowest in the month of January (92.03).

Seasonal price variation of small size native chicken (Bellow 700gm) at National level
The seasonal price indices of medium size native chicken at national level during 2010-2014 are shown in Appendix Table 5. It is illustrated from the table that the price index was highest in the month of August (105.53) and lowest in the month of January (92.87).

\section{Coefficient of variation}

In retail level, the coefficient of variation of broiler is highest in Dhaka Sadar (8.35) followed by Savar market (7.42) indicating at Dhaka Sadar price risk of broiler is higher compare to Savar market. In national level, coefficient of variation of native chicken was found the highest for medium (5.43) followed by small (4.56) and large (4.51) size of poultry bird meaning that the price risk was the highest for medium and lowest for large size of poultry bird (Table 16).

In general, the study found that the price of broiler and native chicken was fluctuated in different seasons. The reasons for fluctuation might be:

I. The price of broiler was lower in the month of mid-November to January. The causes might be supply of broiler on those months increased and consumer's demand decreased.

II. During the month of February to October the broiler price was almost same in nature and the price fluctuation is very little. The supply of and demand for broiler was static over the month.

III. In case of native chicken, price was lower in the month of December to January. The reason might be diseases (ND) out broken (especially Newcastle) on those months was high and demand for native chicken would reduce.

IV. In between mid-May to mid-September the price of native chicken was higher and more or less static in nature during those time periods. It might be fresh and healthy chicken were available in the market and demand was also increased due to various occasions such as marriage ceremony, picnic party, Eid, Puja, and so on.

\section{Processed poultry meat (Halal Method)}

The study revealed that 56 per cent consumer showed negative opinion in case of processed poultry meat indicating that policy should be addressed for the motivation issues of consumers. Processed poultry meat market development is now a demand for modern era.

\section{Consumer preference towards different poultry species}

Study found that consumer preferred native chicken, broiler and sonali by $40 \%, 39 \%$ and $22 \%$, respectively in the areas. It indicated that the demand for native chicken is very high although the price of native chicken is higher compare to other poultry species. The reasons might be better taste to the consumers.

Knowledge about disease outbreak and middlemen attacked by diseases

Due to marketing of live poultry various diseases outbreak and attack the human health and other poultry species. The study explored that 64 per cent respondent had no idea about the disease outbreak. Market actors who did live poultry business suffered various diseases. About 58 per cent market actors attacked by the diseases frequently.

Table 16. Coefficient of variation of broiler and native chicken

\begin{tabular}{|c|c|c|c|c|c|}
\hline \multirow{3}{*}{ Coefficient of variation $(\mathrm{CV})$} & \multicolumn{2}{|c|}{ Brioler } & \multicolumn{3}{|c|}{ Native chicken } \\
\hline & Dhaka Sadar Market & Savar Market & Large & Medium & Small \\
\hline & 8.35 & 7.42 & 4.51 & 5.43 & 4.56 \\
\hline
\end{tabular}


Seasonal Price Index

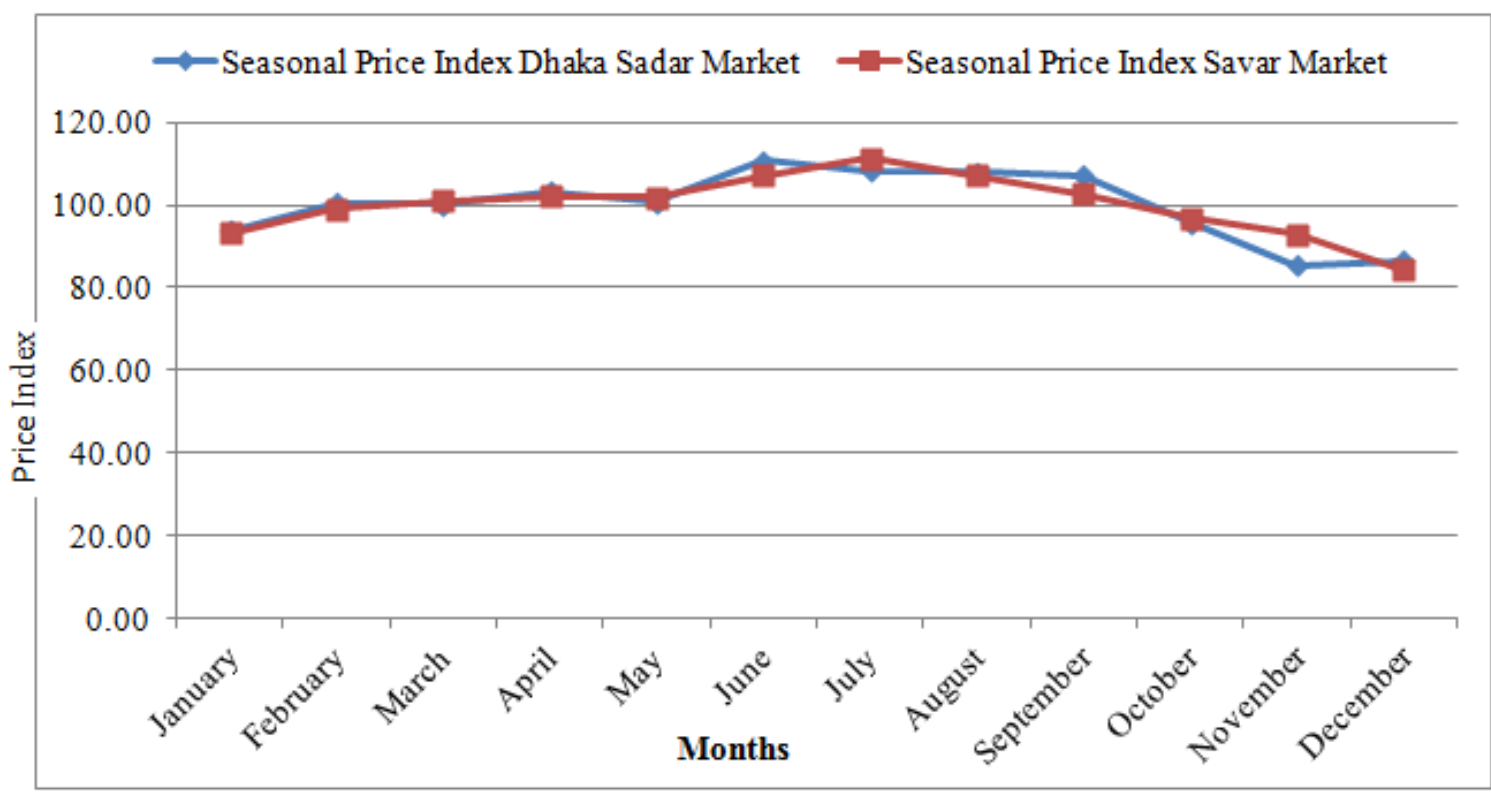

Figure 6. Seasonal Price Index of Broiler in Retail Level of Dhaka Sadar and Savar Market

Seasonal Price Index

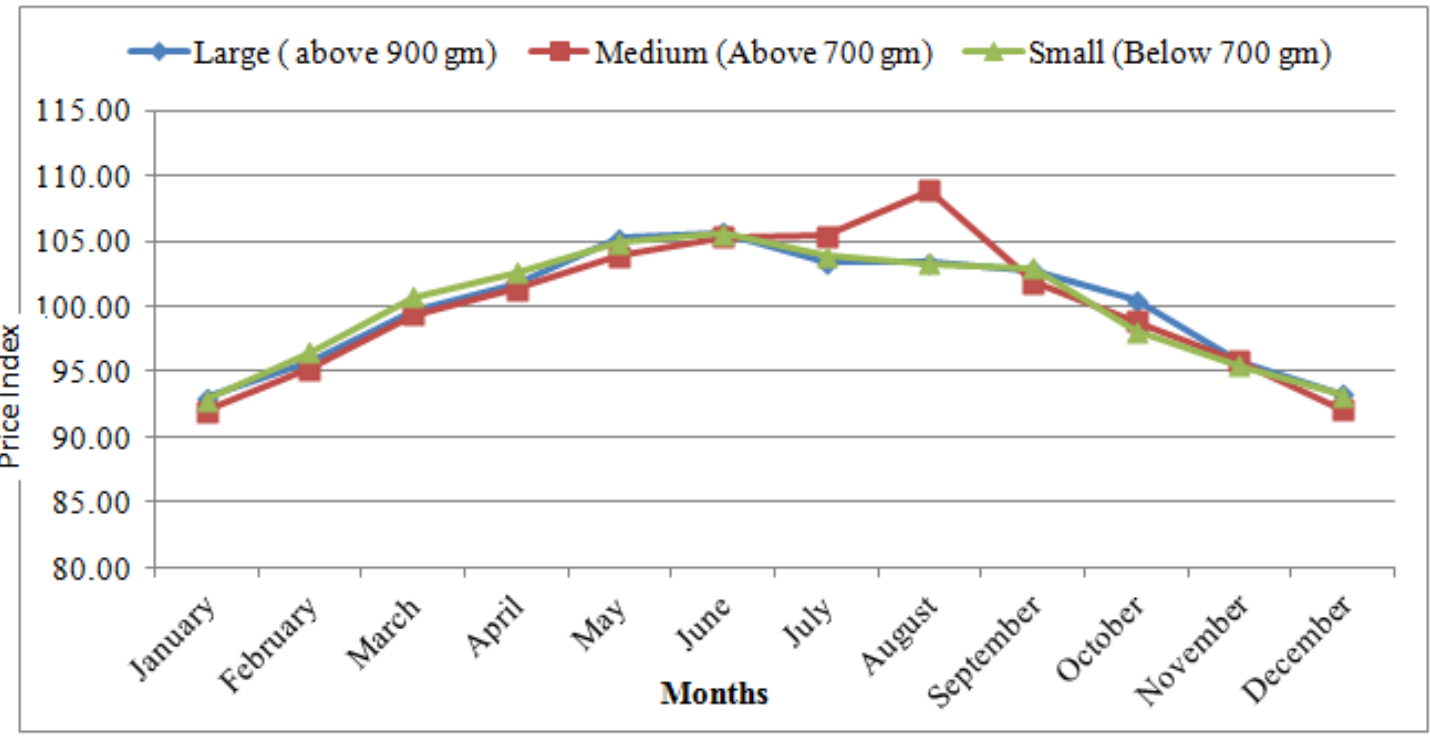

Figure 7. Seasonal Price Index of Native Chicken in National Level

\section{Middlemen attacked by major diseases}

The study identified a number of diseases that occurred and attacked the market actors. It is revealed that 45 per cent attacked by fever and cough cold, 28 per cent cough cold, 17 per cent fever only and 9 per cent asthma.

\section{Major diseases}

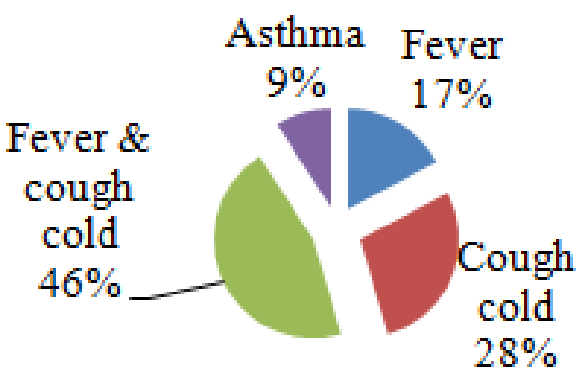

\section{Conclusion and Recommendation}

Poultry production and marketing undoubtedly is a profitable business. For sustainable, environment friendly and standard economy for poultry business, it needs modern and updated steps by govt. and private organization for encouraging the rural youth and women as it brings additional income with low capital investment. Ensuring bio-security, Halal method and hygienic way of poultry processing may be the steps for modern economic system of poultry business.

For sustainable, environment friendly and standard economy for poultry business, it needs modern and updated steps as follows:

- Live poultry marketing should be restricted.

- Mini poultry processing plant should be established throughout the country especially poultry production concentrated areas. 
- Establish legal body for quality testing and certification of processed poultry meat.

- Dump poultry processing waste product in specific dumping place to safe guard the environment.

- Build up awareness about the hazards of live poultry marketing and transportation.

\section{References}

[1] Acharya, S. S. and Agarwal, N. L. (1994). Agricultural Marketing in India. New Delhi, Oxford and EH Publishing Co. Pvt. Ltd. Pp-125-140.

[2] BBS (2013). Statistical Yearbooks. Bangladesh. Bangladesh Bureau of Statistics, Statistics Division, Ministry of Planning, Government of the People's Republic of Bangladesh, Dhaka, Bangladesh.

[3] Begum, I. A., (2008). Prospects and Potentialities of Vertically Integrated Contract Farming in Bangladesh, Unpublished PhD thesis, Department of Agricultural Development Economics, Hokkaido University, Japan.

[4] CLP Market Assessment (2010). Market System for des chicken/eggs-Gaibandha chars.
[5] DLS (2015). Department of Livestock Services, Ministry of Fisheries and Livestock, Government of the Peoples' Republic of Bangladesh, Dhaka.

[6] Department of Agricultural Marketing, (DAM). District Wise Monthly Wholesale Price of Native Chicken and Broiler of Bangladesh, Ministry of Agriculture, Government of the Peoples' Republic of Bangladesh, Dhaka.

[7] FAO (2008). Poultry Sector Country Review-Bangladesh by Frands Dolberg. http://www.fao.org/3/a-ai319e.pdf.

[8] International Food Policy Research Institute (2003). Demand projections for poultry products and poultry feeds in Bangladesh by Nabiul Islam, Markets and Structural Studies Division, 2003 K Street, N.W. htt://www.ifpri.org.

[9] Prabakaran, R., (2003). Good Practices in Planning and Management of Integrated Commercial Poultry Production in South Asia, FAO Animal production and health paper, 159, Food and Agriculture Organization of the United Nations, Rome, Italy.

[10] Tomek, W.G. and Robinson, K. L. (1990). Agricultural Product Prices, $3^{\text {rd }}$ ed., Cornell University Press.Ithaca and London.

[11] Uddin, MT., Islam, MM., Salam, S., and Yasmin, S. (2013). Economics of native poultry rearing in the coastal regions of Bangladesh. Bang. J. Anim. Sci. 2013.42 (1): 49-56.

[12] USDA (United States Department of Agriculture). Agriculture Fact Book 1998. Chapter 1. Online. Retrieved June 7, 1999. http://www.usda.gov/news/pubs/fbook98/chart1.htm.

\section{Appendix Tables}

Table 1. Retail Level Seasonal price index of Broiler in Dhaka Sadar Market (2010-2014)

\begin{tabular}{|l|c|c|c|c|c|c|c|}
\hline Months Year & 2010 & 2011 & 2012 & 2013 & 2014 & $\begin{array}{c}\text { Seasonal Indices } \\
\text { (Mean) }\end{array}$ & Adjusted SI \\
\hline January & & 85.38 & 98.53 & 100.14 & 91.84 & 93.97 & 93.88 \\
\hline February & & 91.36 & 105.92 & 102.64 & 102.34 & 100.57 & 100.47 \\
\hline March & & 96.06 & 101.54 & 101.84 & 101.27 & 100.18 & 100.08 \\
\hline April & & 102.71 & 107.12 & 102.68 & 101.24 & 103.44 & 103.33 \\
\hline May & & 96.84 & 107.50 & 97.76 & 100.78 & 100.72 & 100.62 \\
\hline June & & 113.83 & 113.36 & 105.28 & 111.31 & 110.95 & 110.83 \\
\hline July & 101.63 & 113.95 & 102.93 & 114.69 & & 108.30 & 108.19 \\
\hline August & 106.13 & 106.22 & 107.34 & 112.87 & & 108.14 & 108.03 \\
\hline September & 134.10 & 94.40 & 102.65 & 97.93 & & 107.27 & 107.16 \\
\hline October & 104.45 & 94.99 & 92.87 & 91.37 & & 95.92 & 95.82 \\
\hline November & 91.74 & 78.45 & 85.52 & 85.97 & & 85.42 & 85.33 \\
\hline December & 76.31 & 91.10 & 91.11 & 87.38 & & 86.48 & 86.39 \\
\hline Total & & & & & & 1201.35 & 1200.15 \\
\hline
\end{tabular}

Source: DAM (2010-2014)

Here, $\mathrm{K}=0.999$.

Table 2. Retail Level Seasonal price index of Broiler in Savar Market (2010-2014)

\begin{tabular}{|c|c|c|c|c|c|c|c|}
\hline Months Year & 2010 & 2011 & 2012 & 2013 & 2014 & $\begin{array}{c}\text { Seasonal Indices } \\
\text { (Mean) }\end{array}$ & Adjusted SI \\
\hline January & & 88.85 & 90.74 & 102.53 & 91.43 & 93.39 & 93.11 \\
\hline February & & 92.04 & 96.96 & 103.34 & 104.86 & 99.30 & 99.01 \\
\hline March & & 96.24 & 105.85 & 104.11 & 99.54 & 101.44 & 101.13 \\
\hline April & & 99.75 & 105.66 & 99.09 & 105.69 & 102.55 & 102.24 \\
\hline May & & 99.51 & 102.89 & 99.76 & 106.76 & 102.23 & 101.92 \\
\hline June & & 103.19 & 116.47 & 99.55 & 110.55 & 107.44 & 107.12 \\
\hline July & 102.25 & 116.21 & 112.34 & 115.57 & & 111.59 & 111.26 \\
\hline August & 102.41 & 104.40 & 104.33 & 118.94 & & 107.52 & 107.20 \\
\hline September & 112.88 & 97.40 & 105.53 & 95.97 & & 102.95 & 102.64 \\
\hline October & 104.69 & 98.62 & 93.33 & 92.15 & & 97.20 & 96.91 \\
\hline November & 111.24 & 88.26 & 87.11 & 85.62 & & 93.06 & 92.78 \\
\hline December & 80.57 & 85.97 & 86.20 & 85.14 & & 84.47 & 84.22 \\
\hline Total & & & & & & 1203.12 & 1199.51 \\
\hline
\end{tabular}

Source: DAM (2010-2014)

Here, $\mathrm{K}=0.997$. 
Table 3. National Level Seasonal price index of Large Native Chicken (2010-2014)

\begin{tabular}{|c|c|c|c|c|c|c|c|}
\hline Months $\quad$ Year & 2010 & 2011 & 2012 & 2013 & 2014 & $\begin{array}{c}\text { Seasonal Indices } \\
\text { (Mean) }\end{array}$ & Adjusted SI \\
\hline January & & 91.88 & 92.49 & 93.97 & 93.34 & 92.92 & 92.97 \\
\hline February & & 92.17 & 96.04 & 96.88 & 97.75 & 95.71 & 95.76 \\
\hline March & & 96.37 & 102.85 & 99.67 & 99.47 & 99.59 & 99.64 \\
\hline April & & 98.75 & 105.15 & 101.45 & 101.42 & 101.69 & 101.75 \\
\hline May & & 105.78 & 107.70 & 103.34 & 103.86 & 105.17 & 105.23 \\
\hline June & & 104.46 & 108.49 & 102.92 & 106.46 & 105.58 & 105.64 \\
\hline July & 99.90 & 104.50 & 104.67 & 104.03 & & 103.27 & 103.33 \\
\hline August & 100.12 & 104.34 & 104.30 & 104.59 & & 103.34 & 103.40 \\
\hline September & 104.48 & 101.93 & 102.10 & 102.39 & & 102.73 & 102.79 \\
\hline October & 103.37 & 99.20 & 99.92 & 99.14 & & 100.41 & 100.47 \\
\hline November & 98.45 & 92.06 & 96.21 & 96.06 & & 95.70 & 95.75 \\
\hline December & 96.43 & 89.10 & 94.44 & 92.80 & & 93.19 & 93.25 \\
\hline Total & & & & & & 1199.3 & 1199.99 \\
\hline
\end{tabular}

Source: DAM (2010-2014)

Here, $\mathrm{K}=1.00058$.

Table 4. National Level Seasonal price index of Medium Native Chicken (2010-2014)

\begin{tabular}{|c|c|c|c|c|c|c|c|}
\hline Months Year & 2010 & 2011 & 2012 & 2013 & 2014 & $\begin{array}{c}\text { Seasonal Indices } \\
\text { (Mean) }\end{array}$ & Adjusted SI \\
\hline January & & 94.16 & 89.99 & 93.28 & 91.54 & 92.24 & 92.03 \\
\hline February & & 92.54 & 95.19 & 96.30 & 97.72 & 95.44 & 95.22 \\
\hline March & & 94.16 & 104.02 & 100.42 & 99.68 & 99.57 & 99.34 \\
\hline April & & 96.83 & 105.32 & 102.34 & 101.71 & 101.55 & 101.31 \\
\hline May & & 100.53 & 107.33 & 103.73 & 105.00 & 104.15 & 103.91 \\
\hline June & & 102.53 & 108.58 & 104.30 & 106.76 & 105.55 & 105.30 \\
\hline July & 101.51 & 103.43 & 104.95 & 105.09 & 109.14 & 105.65 & 105.41 \\
\hline August & 101.19 & 125.90 & 104.31 & 105.01 & & 109.10 & 108.85 \\
\hline September & 104.96 & 99.36 & 101.74 & 102.29 & & 102.09 & 101.85 \\
\hline October & 103.35 & 95.08 & 99.37 & 98.58 & & 99.10 & 98.86 \\
\hline November & 101.48 & 91.45 & 96.37 & 94.92 & & 96.05 & 95.83 \\
\hline \multirow[t]{2}{*}{ December } & 95.95 & 88.56 & 93.42 & 91.35 & & 92.32 & 92.10 \\
\hline & & & & & & 1202.8 & 1200 \\
\hline
\end{tabular}

Source: DAM (2010-2014)

Here, $\mathrm{K}=0.9976$.

Table 5. National Level Seasonal price index of Small Native Chicken (2010-2014)

\begin{tabular}{|c|c|c|c|c|c|c|c|}
\hline Month Year & 2010 & 2011 & 2012 & 2013 & 2014 & $\begin{array}{c}\text { Seasonal Indices } \\
\text { (Mean) }\end{array}$ & Adjusted SI \\
\hline January & & 93.86 & 92.93 & 93.54 & 91.04 & 92.84 & 92.87 \\
\hline February & & 93.41 & 97.05 & 97.60 & 97.90 & 96.49 & 96.52 \\
\hline March & & 96.32 & 104.46 & 102.10 & 100.05 & 100.73 & 100.77 \\
\hline April & & 98.68 & 106.90 & 102.34 & 102.16 & 102.52 & 102.55 \\
\hline May & & 102.54 & 108.50 & 103.09 & 105.17 & 104.82 & 104.86 \\
\hline June & & 104.44 & 108.23 & 103.00 & 106.31 & 105.49 & 105.53 \\
\hline July & 101.84 & 105.14 & 104.45 & 103.96 & & 103.85 & 103.88 \\
\hline August & 99.21 & 103.53 & 104.55 & 105.67 & & 103.24 & 103.27 \\
\hline September & 105.77 & 101.50 & 101.23 & 103.14 & & 102.91 & 102.95 \\
\hline October & 102.46 & 92.87 & 98.14 & 98.82 & & 98.07 & 98.10 \\
\hline November & 97.82 & 92.96 & 96.01 & 95.07 & & 95.46 & 95.49 \\
\hline December & 98.23 & 89.50 & 94.02 & 90.96 & & 93.18 & 93.21 \\
\hline Total & & & & & & 1199.61 & 1200 \\
\hline
\end{tabular}

Source: DAM (2010-2014)

Here, $\mathrm{K}=1.000325$ 